Vol. 2, $\mathbf{N}^{\circ} 1,2020$

\section{Journal of Global \\ Education Sciences}

\title{
Fundamentals of Education vs communication [Fundamentos de la educación vs comunicación]
}

\author{
Vanessa Olaguibel ${ }^{*}$ \\ *vdolaguibelv@gmail.com
}

Received: 11 June 2020; Accepted: 21 November 2020; Published: 13 December 2020

\section{Resumen}

La educación tiene fundamentos que permiten una comunicación más fluida que muy poco ha sido explotada. Este articulo pretende motivar a aplicar los fundamentos de la educación a los estudiantes de nivel inicial, básico y superior.

Palabras clave: Educación, fundamentos, comunicación, profesor,

Abstract

Education has foundations that allow more fluid communication that very little has been exploited. This article tries to motivate to apply the fundamentals of the education to the students of initial, basic and superior level.

Keywords: Education, Fundamental, communication, professor.

\section{Introduction}

Education and communication are considered two latent social phenomena in all the ages. The socio-cultural impact that you are causing in society are determining factors when establishing a global analysis of the development of each city, province, country and region Four Foundations of Education (Pozo, 1999) Education is a process of daily and continuous training, where the subject is exposed to a series of conditions clearly typical of daily life, the process of pedagogical training becomes meaningful only if the following points are considered within the curriculum:

\section{Learn to know}

Considering that today education has become a challenge, one of the greatest challenges is precisely learning to know; Very few people get to this point, and despite various efforts to achieve it, it is simply impossible at times; and is that the problem lies in a lack of guidance so that the student can achieve it. 


\section{Journal of Global Education Sciences}

Vol. 2, $\mathbf{N}^{\circ} 1,2020$

When the subject learns to know, he learns to separate and articulate the concrete from the abstract and, above all, to reflect judiciously on any issue that comes his way, he knows that all problems have solutions, likewise he cannot be left with a single alternative, but look for multiple paths for their respective solution.

\section{Learn to do}

Learning to know does not make sense if you do not learn to do it, because the theoretical justification always recovers its digits with experimentation, it is useless for a subject whatever this may be, to know something if in the end they cannot put it into practice; that is why learning to know and learn to do cannot be assimilated one separately from the other.

Learning to do the subject also develops the creative capacity, the capacity for innovation, fundamental weapons for the human being to acquire new skills and their development is no longer limiting, leave the framework of believing that everything is pigeonholed in the classroom and that become part of those who believe that the true conquest is in freedom, thought must also reach that state and it is there precisely when the human being begins to see life from another perspective and begins to realize that the essence of things are in the development and the ability to face the obstacles and challenges of life.

\section{To learn to live together}

Today it constitutes a difficult task, since the wave of modernity has imposed as one of its ideals the individualization of the subject, leading him to be mean with others and to erase from his memory the sense of unity and communion, in such a way that the subject has become a cold machine that is programmed only to produce for himself.

Within this process, the intervention of communication is essential and fundamental, because only through it is it possible to fully know the self and the other, establish contact and begin the process known as interaction, through communication it is also possible to achieve closer ties of union, which is a way to a certain extent to guarantee mutual understanding and coexistence between the subjects "The main task of education is to deepen the democratic ideal and consolidate respect for cultural, religious and ideological pluralism, more to persist in an illusory homogenized universalism, to guarantee understanding "(Pozo, 1999).

\section{Learn to Be}

The subject must develop at the same age as his age, contrary to what Piaget proposes, it is necessary for the child to be a child, and not for it to be an adult because society demands and needs it, the child has to learn to Live your own world to play when it is to play and does not hold back by the desire of others.

\section{The communication}

Communication is such a complex process that a single definition cannot be attributed to it, more historically there have been different conceptualizations regarding its meaning, it all depends from the philosophical point of view that it is seen; To which must be added that it is a polysemic word, that is, it has multiple meanings, therefore it is usually specified according to the historical, social, cultural, military and even academic context in which it unfolds. Turning the pages of history, it dates that the word communication as such appears for the first time in Ancient Greece, and is used by Plato and Aristotle, but it is not until modernity that it acquires a great significance, realizing that communication can never be detached from science, art and culture (Baylon and Mignot, 1996). 


\section{Journal of Global Education Sciences}

Vol. 2, $\mathrm{N}^{\circ}$ 1, 2020
A publication of

\section{CINCADER}

Centre of Research and Training for

Regional Development

Online at www.journals.cincader.org

Copyright (c) 2020, CINCADER.

ISSN 2663-3787

DOI: https://doi.org/10.32829/ges.v2i1.202

\section{Conclusions}

- Today's education requires breaking schemes, moving from communication vertical and authoritarian to a democratic and horizontal communication that promote didactics and group participation within the educational context.

- In the teaching-learning process there is definitely an educommunicative interaction, in addition to the word, every act, gesture, movement and behavior connotes an important significance that contributes to the construction of new knowledge

\section{References}

Baylon, Cristián y Mignot, Xavier. 1996. “La comunicación”, Ediciones Cátedra, Madrid-España,

Pereira Valarezo, A. 2002. Semiotica y Comunicacion. Quito: Ediciones Cientificas Agustin Alvarez CIA L.T.D.A

Pozo, Juan. 1999. "El aprendizaje estratégico", ed. Santillana. 